\title{
The Effect of a Training Program for Developing Motor Capabilities on Katame.Waza Skills in Judo
}

Nevin Hussein*

Sport training aims at raising the skill, plan, physical and psychological capabilities of the beginners to become efficient and of a higher standard. The researcher noticed, through working in judo field, the failure of most of the beginners to defence and that it was difficult for them to perform the counter-attack in a skill of Katame.Waza and to continue for 25 seconds in Oseekomy. Waza skills. As a result, the beginners take a long time in training process to perfect the performance of Katame.Waza skills. Thus, the aim of the current study is to design a training program to develop certain motor capabilities of Oseekomy.Waza skills in Katame.Waza (motor response speed, speedy power, agility, and muscular endurance). The researcher used the experimental method using the pre and post measurements of the experimental group and the control group. The population was 68 beginners selected from Zamalek Sports Club. A pilot sample was 56 beginners that represent the judo weights. The researcher applied the proposed experimental program of 8 weeks, three times a week and each lesson took 90minutes. There are statistically significant differences between the two post tests of the experimental group and the control in favor of the experimental group. There is also a correlation between the motor capabilities and the performance level of some skills of defence, counter-attack of Katame.Waza.

Key words: motor capabilities, defence, counter-attack.

\section{Introduction}

$\mathrm{M}$ otor capabilities have a large number of physical fitness components which are nine (the muscular power, muscular endurance,

Cardiovascular respiratory endurance, flexibility, agility, balance, speed, foot-eye coordination, and arm-eye coordination).

Developing these motor capabilities helps in achieving the highest performance level of the motor skills that is always tied to the physical fitness components in the different sports activities. ( Sobhy, 2000) (Fathy, 2004) (Abd ELkhalik, 2007).

Judo is a competitive sport that requires a speedy and dynamic performance all the game time with the minimum of effort and with the

*Assistant Professor, Faculty of Physical Education for Girls, Zagazig University, Egypt. maximum of motor skills by using practical and modern methods in training and the various ways of performance. These skills include Naga.Waza and Katame.Waza skills that require mental and physical efforts. (Abd Elraouf, 2005) (Hamed, 2008)

It is necessary to care about judo skills, and the player must be skillful and prepared physically to achieve integrated movements aimed at improving the motor capabilities whether in Naga.Waza or Katame.Waza skills. Judo requires a constant change from defence and attack between uki and tori all the game time, so a judo player should not have one particular skill because this will affect his/her performance plan and will also help his/her opponent to escape and to counter-attack. (Moto, 2004) (Hikoichi, 2000).

A judo player should be skillful and prepared physically and psychologically. Since judo is a contact sport, practicing it requires permanent thinking. This is because of the difficulty of its 
performance, the variety of its skills, and the different and changeable situations during the contest. Therefore, a judo player should be fully alert to face any changes during the contest. $\mathrm{He} / \mathrm{She}$ should also concentrate on the selected playing plans that require motor power, cheating, rotation, control, subjugation and require constant performance done smoothly, and that is the soul of the training process. (Takahashashi , 2005) (Ohlen, 2006) (Angus, 2005).

Katame.Waza is an important means to win because it has a lot of individual and compound motor performances that are not identical concerning their components and their aims. The player merges these components together in a smooth continuous performance. Besides, these components make the performance highly coordinated. Thus, a judo player should be continuously trained the attack, the positive defence, the counter-attack and the compound counter-attack because strength is not enough but the performance and the motor capabilities of the player is the only way to win. (Hamed, 2010) (Husein, 2010) (Pedro, 2009).

\section{Research problem}

The researcher noticed, through working in judo field, the failure of most of the beginners to defence and that it was difficult for them to perform the counter-attack in a skill of Katame.Waza and to continue for 25 seconds in Oseekomy.Waza skills. These skills play an important role in all contests because they are a complement to Nage.Waza skills when the player fails to end the game with one of these skills. It takes a long time for the beginners to perfect the performance of Katame.Waza skills. Some of the beginners cannot do these skills, and the repetition of performing them is not enough to improve the performance levels, and this can be seen in mistakes they make. The researcher thinks that this because they lack of some motor capabilities and the defence and attack thinking in Katame.Waza.

\section{Aim of the study}

The aim of the study is to design a proposed training program for judo beginners to identify its effect on certain defence and counter-attack skills of Oseekomy.Waza, for:

1. Developing certain motor capabilities of Oseekomy.Waza (motor response speed, speedy power, agility, muscular endurance) in Katame.Waza in judo.

2. Improving the performance level of some defence skills (pulling the opponent and turn him/her to the other side - pushing the opponent upwards and throw him to either sides - pushing the opponent's head and move the leg in a circle around his neck) and some counter-attack skills(Yoko Shiho Gatame, Kami Shiho Gatame and Kesa Gatame) for both sides of the body.

\section{Method}

The researcher used the experimental method using the pre and post tests of the experimental group and the control group, and that is suitable to the research nature.

\section{Population and sample}

The population was 68 beginners selected from Zamalek Sports Club in Cairo, 2 of them were excluded because they were injured. A pilot sample of 10 was selected randomly to find the coefficients and the pilot experiments. Thus, the sample becomes 56 beginners, divided equally into two groups, the experimental group and the control group, representing judo weights. The results showed that the skewness coefficients are ranged from 1.22 to 0.56 , which was restricted between $r+$ indicating data normality. This shows the normality and homogeneity of the population in (growth rates, the motor capabilities and the performance level).

\section{Data collecting tools}

\section{Tools and equipment:}

A Wristmeter to measure height and weight (in centimeters and kilograms), a stop watch to measure the time per second, climbing ropes, a 
constructive mode and judo felt mat, Forms and interviews.

2. Tests and measurements:

\section{Skill tests}

- Pulling the opponent and turn him to the other side (per second)

- Pushing the opponent upwards and moving in circle to any direction (per second)

- Pushing the attacker's head with the arm and moving the leg around his neck (per second)

\section{Motor capabilities tests:}

- Uch Komi test with moving backwards to measure the motor response speed (per second)

- The circular throwing ,by the different skills, test to measure the muscular endurance (per second)

- Uchi Mata semi-circular test to measure agility (per second)

- Side-throwing, by the different skills, test to measure speedy power (per second)

\section{Validity}

The researcher used distinction validity to verify the selected tests validity, and the calculated $\mathrm{T}$ value was at $0.05=2.10$.

\section{Reliability}

The reliability was calculated by applying "Test-Re test". The correlation coefficient was 0.632 .

\section{The pre measurements:}

The skill and physical tests are measured from 28-29/9/2010.

\section{Applying the program:}

The researcher applied the suggested program for 8 weeks, three times a week and each lesson took 90minutes, from 30/9/2010 to 30/11/2010, according to the experts' opinions, The periodic method of training (of a high and a low intensity) was used starting from $50 \%$ to $70 \%$, from the highest point of what the beginner can endure. It was the determined through the heart beat rate.

The post measurements:

The post measurements of all variables studied were conducted from $1 / 12 / 2010$ to $2 / 12 / 2010$ 


\section{Results}

Table 1: Significant differences between the pre and post tests and progress ratio in the physical capabilities of the control group

(n1=n2=28)

\begin{tabular}{|c|c|c|c|c|c|c|}
\hline \multirow{2}{*}{ Physical tests } & \multicolumn{2}{|c|}{ pre measurements } & \multicolumn{2}{|c|}{$\begin{array}{c}\text { post } \\
\text { measurements }\end{array}$} & \multirow{2}{*}{$\begin{array}{c}\text { T. } \\
\text { Test }\end{array}$} & \multirow{2}{*}{$\begin{array}{c}\text { Progress } \\
\%\end{array}$} \\
\hline & Mean & $\begin{array}{l}\text { Standard } \\
\text { deviation }\end{array}$ & Mean & $\begin{array}{l}\text { Standard } \\
\text { deviation }\end{array}$ & & \\
\hline $\begin{array}{l}\text { A. Uchi Komi with moving backwards } \\
\text { to measure (response speed) from the } \\
\text { right side. }\end{array}$ & 6.339 & 8.29 & 0.797 & $v . r \cdot r$ & $\cdot \wedge T 1$ & $11 . \mathrm{rA}$ \\
\hline $\begin{array}{l}\text { B. Uchi Komi with moving backwards } \\
\text { to measure (response speed) from the } \\
\text { left side. }\end{array}$ & 5.035 & 0.998 & $\varepsilon . \leqslant 7 \leqslant$ & $\because .991$ & $* r .1 \mu q$ & Ir.A \\
\hline $\begin{array}{l}\text { C. Circular throwing, by the different } \\
\text { skills, test to measure (muscular } \\
\text { endurance) from the right side. }\end{array}$ & 8.85 & 0.867 & 9.0 & $1.77 \mathrm{~V}$ & *Y.וT & V.ro \\
\hline $\begin{array}{l}\text { D. Circular throwing, by the different } \\
\text { skills, test to measure (muscular } \\
\text { endurance) from the left side. }\end{array}$ & 6.5 & 0.407 & $V . Y I \leq$ & $1 . r 09$ & $* Y . \wedge \varepsilon$ & $1 \cdot .91$ \\
\hline $\begin{array}{l}\text { E. Uchi Mata semi-circular test to } \\
\text { measure (agility) from the right side. }\end{array}$ & 27.46 & 1.146 & r. & r.r人 & $* Y .79$ & $\varepsilon .0$ \\
\hline $\begin{array}{l}\text { F. Uchi Mata semi-circular test to } \\
\text { measure (agility) from the left side. }\end{array}$ & 29.21 & 1.28 & $r v . \wedge q$ & $\varepsilon .0 \leqslant$ & $* Y . \wedge q$ & 28.81 \\
\hline $\begin{array}{l}\text { G. Side- throwing, by the different skills, } \\
\text { test to measure (speedy power) from } \\
\text { the right side. }\end{array}$ & 4.42 & 1.66 & $0 . r_{0}$ & r.or & *r. rq & $Y \cdot .97$ \\
\hline $\begin{array}{l}\text { H. Side- throwing, by the different skills, } \\
\text { test to measure (speedy power) from } \\
\text { the left side. }\end{array}$ & 3.928 & 2.21 & $\varepsilon . \wedge r$ & r.A9 & $* Y . \cdot 9$ & YY.VY \\
\hline
\end{tabular}

Table 1 shows the differences between the pre and post tests of the control group in the beginners' physical level and this slight progress in the physical level is because training was done regularly and took long time. 
Table 2: Significant differences between the pre and post tests in the skill tests of the control group

$(n 1=n 2=28)$

\begin{tabular}{|c|c|c|c|c|c|c|}
\hline \multirow{2}{*}{ Physical tests } & \multicolumn{2}{|c|}{$\begin{array}{c}\text { Pre } \\
\text { measurements }\end{array}$} & \multicolumn{2}{|c|}{$\begin{array}{c}\text { post } \\
\text { measurements }\end{array}$} & \multirow{2}{*}{$\begin{array}{c}\text { T. } \\
\text { Test }\end{array}$} & \multirow{2}{*}{$\begin{array}{l}\text { Progress } \\
\%\end{array}$} \\
\hline & Mean & $\begin{array}{l}\text { Standard } \\
\text { deviation }\end{array}$ & Mean & $\begin{array}{l}\text { Standard } \\
\text { deviation }\end{array}$ & & \\
\hline $\begin{array}{l}\text { A. Pulling the opponent and turn him to } \\
\text { the right side and escape from Kesa } \\
\text { Gatame skill. }\end{array}$ & $\varepsilon .0$ & 0.10 & $\varepsilon .9 T$ & 0.99 & $\cdot .774$ & $9.0 \%$ \\
\hline $\begin{array}{l}\text { B. Pulling the opponent and turn him to } \\
\text { the right side and Oseekamy by Kesa } \\
\text { Gatame skill. }\end{array}$ & $\varepsilon . \wedge \vee$ & $\varepsilon . \wedge \vee$ & 0.11 & 0.17 & .00 & 7.21 \\
\hline $\begin{array}{l}\text { C. Pulling the opponent and turn him to } \\
\text { the left side and escape from Kesa } \\
\text { Gatame skill. }\end{array}$ & $\varepsilon . \Gamma q$ & IY.rs & $\varepsilon . \vee \leq$ & $11 . r r$ & . & $V . r I$ \\
\hline $\begin{array}{l}\text { D. Pulling the opponent and turn him to } \\
\text { the left side and Oseekamy by Kesa } \\
\text { Gatame skill. }\end{array}$ & $\varepsilon .1 \varepsilon$ & $\varepsilon . r$. & $\varepsilon . V Y$ & $0.1 \mathrm{~V}$ & $\because .91$ & 17.89 \\
\hline $\begin{array}{l}\text { E. Pushing the opponent upwards and } \\
\text { moving in a circle to the right side and } \\
\text { escape from Kami Shiho Gatame skill. }\end{array}$ & $\varepsilon .7 \varepsilon$ & $\Lambda_{.} \cdot 1$ & $\varepsilon .97$ & 7.. & $\cdot \varepsilon \varepsilon$ & $7.9 r$ \\
\hline $\begin{array}{l}\text { F. Pushing the opponent upwards and } \\
\text { moving in a circle to the right side and } \\
\text { OseeKomy by Kami Shiho Gatame } \\
\text { skill. }\end{array}$ & $\varepsilon . \wedge \vee$ & $\varepsilon . \leqslant V$ & 0 & $\varepsilon . r \varepsilon$ & $\cdot r \Lambda$ & $\varepsilon . \leqslant V$ \\
\hline $\begin{array}{l}\text { G. Pushing the opponent upwards and } \\
\text { moving in a circle to the left side and } \\
\text { escape from Kami Shiho Gatame skill. }\end{array}$ & 0.97 & $1 \cdot . \wedge 0$ & $7.1 \mathrm{~V}$ & 11.11 & $\because r \leq$ & $r .09$ \\
\hline $\begin{array}{l}\text { H. Pushing the opponent upwards and } \\
\text { moving in a circle to the left side and } \\
\text { OseeKomy by Kami Shiho Gatame } \\
\text { skill. }\end{array}$ & $\varepsilon . \mu_{0}$ & $\varepsilon .9 V$ & $\varepsilon .04$ & $\varepsilon .74$ & $\cdot r \cdot \varepsilon$ & $\varepsilon .99$ \\
\hline $\begin{array}{l}\text { I. Pushing the opponent's head with the } \\
\text { arm and moving the leg around his } \\
\text { neck to the right side and escape from } \\
\text { Yoko Shiho Gatame skill. }\end{array}$ & $\varepsilon .7 \varepsilon$ & ^.+1 & $\varepsilon . \vee \wedge$ & $\Lambda . r \leq$ & $\because 1 \mathrm{AV}$ & $r . \cdot v$ \\
\hline $\begin{array}{l}\text { J. Pushing the opponent's head with the } \\
\text { arm and moving the leg around his } \\
\text { neck to the right side and OseeKomy } \\
\text { by Yoko Shiho Gatame skill. }\end{array}$ & $\varepsilon . \vee \wedge$ & $\varepsilon . \leqslant V$ & $\varepsilon .9 T$ & $\varepsilon .01$ & r TOY & $r .91$ \\
\hline $\begin{array}{l}\text { K. Pushing the opponent's head with the } \\
\text { arm and moving the leg around his } \\
\text { neck to the left side and escape from } \\
\text { Yoko Shiho Gatame skill. }\end{array}$ & $\varepsilon .0 \mathrm{~V}$ & 9.77 & 0 & 9.00 & $.01 \mathrm{~V}$ & $9 . r v$ \\
\hline $\begin{array}{l}\text { L. Pushing the opponent's head with the } \\
\text { arm and moving the leg around his } \\
\text { neck to the left side and OseeKomy by } \\
\text { Yoko Shiho Gatame skill. }\end{array}$ & $0.7 \varepsilon$ & 7.17 & 0.71 & 7.9 & $\because .0 r$ & r \\
\hline
\end{tabular}

Table 2 shows the differences between the pre and post tests of the control group in the skill level and this is because of the traditional way of training that leads to slight progress in improving the skill performance level. 
Table r. Significant differences between the pre and post tests and progress ratio in the physical capabilities of the experimental group

$(n 1=n 2=28)$

\begin{tabular}{|c|c|c|c|c|c|c|}
\hline \multirow{2}{*}{ Physical tests } & \multicolumn{2}{|c|}{ pre measurements } & \multicolumn{2}{|c|}{$\begin{array}{c}\text { post } \\
\text { measurements }\end{array}$} & \multirow{2}{*}{$\begin{array}{c}\text { T. } \\
\text { Test }\end{array}$} & \multirow{2}{*}{$\begin{array}{c}\text { Progress } \\
\%\end{array}$} \\
\hline & Mean & $\begin{array}{l}\text { Standard } \\
\text { deviation }\end{array}$ & Mean & $\begin{array}{l}\text { Standard } \\
\text { deviation }\end{array}$ & & \\
\hline $\begin{array}{l}\text { A. Uchi Komi with moving backwards to } \\
\text { measure (response speed) from the right } \\
\text { side. }\end{array}$ & 6.339 & 8.29 & 2.678 & 0.670 & $* 8.93$ & 136.66 \\
\hline $\begin{array}{l}\text { B. Uchi Komi with moving backwards to } \\
\text { measure (response speed) from the left } \\
\text { side. }\end{array}$ & 5.035 & 0.998 & 2.857 & 0.571 & *18.84 & 76.25 \\
\hline $\begin{array}{l}\text { C. Circular throwing, by the different } \\
\text { skills, test to measure (muscular } \\
\text { endurance) from the right side. }\end{array}$ & 8.85 & 0.867 & 14.03 & 1.369 & *37.90 & 58.46 \\
\hline $\begin{array}{l}\text { D. Circular throwing, by the different } \\
\text { skills, test to measure (muscular } \\
\text { endurance) from the left side. }\end{array}$ & 6.5 & 0.407 & 10.35 & 0.608 & $* 45.51$ & 59.34 \\
\hline $\begin{array}{l}\text { E. Uchi Mata semi-circular test to measure } \\
\text { (agility) from the right side. }\end{array}$ & 27.46 & 1.146 & 21.14 & 1.682 & $* 26.78$ & 29.89 \\
\hline $\begin{array}{l}\text { F. Uchi Mata semi-circular test to measure } \\
\text { (agility) from the left side. }\end{array}$ & 29.21 & 1.28 & 22.67 & 1.11 & $* 39.24$ & 28.81 \\
\hline $\begin{array}{l}\text { G. Side- throwing, by the different skills, } \\
\text { test to measure (speedy power) from the } \\
\text { right side. }\end{array}$ & 4.42 & 1.66 & 9.42 & 0.624 & $* 28.06$ & 112.90 \\
\hline $\begin{array}{l}\text { H. Side- throwing, by the different skills, } \\
\text { test to measure (speedy power) from the } \\
\text { left side. }\end{array}$ & 3.928 & 2.21 & 7.21 & 0.619 & *20.34 & 83.63 \\
\hline
\end{tabular}

Table (3) indicated that there are statistically significant differences between the pre and post tests and there is also progress ratio in the variables of the physical capabilities tests of the experimental group in favor of the post test. The researcher attributes the progress in the physical capabilities studied to the proposed program that has regulated training load and intensity and that also contains exercises performed in different directions with moving in a circle and jump. The program also contains other exercises in which tools (climbing ropes - constructive mode) were used. This also led to developing the motor response, muscular endurance, agility and speedy power, involving all body parts, accordingly, developing the motor capabilities with coordination that suits different situations through the game. The physical fitness is the base of performing skills effectively, so it is necessary to determine the beginners' abilities to improve the skill performance according to the contest regulation. ( Hamdy, 2009).

It is also necessary to develop the motor capabilities (speedy power, flexibility, agility, balance, muscular endurance) through physical training programs that meet the requirements of the motor skill performance of the practiced activity. (Ahmed, 2008 ).

All results are agreed with (Mohamed, 1990) and( Abd Elmoneim, 2004).'s indications about the effect of the constant training on improving the physical level gradually. Physical training containing exercises for improving the motor capabilities leads to improve the results of the 
physical performance, and this is called the transmission of the positive impact. All this proved the first hypothesis that there are statistically significant differences between the pre and post tests of the experimental group in certain motor capabilities studied in favor of the post test.

Table ؛: Significant differences between the pre and post tests in the skill tests of the experimental group $(n 1=n 2=28)$

\begin{tabular}{|c|c|c|c|c|c|c|}
\hline \multirow{2}{*}{ Physical tests } & \multicolumn{2}{|c|}{ Pre measurements } & \multicolumn{2}{|c|}{$\begin{array}{c}\text { Post } \\
\text { measurements }\end{array}$} & \multirow{2}{*}{$\begin{array}{c}\text { T. } \\
\text { Test }\end{array}$} & \multirow{2}{*}{$\begin{array}{c}\text { Progress } \\
\%\end{array}$} \\
\hline & Mean & $\begin{array}{l}\text { Standard } \\
\text { deviation }\end{array}$ & Mean & $\begin{array}{l}\text { Standard } \\
\text { deviation }\end{array}$ & & \\
\hline $\begin{array}{l}\text { A. Pulling the opponent and turn him to the } \\
\text { right side and escape from Kesa Gatame } \\
\text { skill. }\end{array}$ & 4.5 & 5.74 & 8.21 & 3.73 & $* 11.73$ & 82.538 \\
\hline $\begin{array}{l}\text { B. Pulling the opponent and turn him to the } \\
\text { right side and Oseekamy by Kesa } \\
\text { Gatame skill. }\end{array}$ & 4.78 & 4.47 & 7.89 & 4.54 & *11.34 & 64.92 \\
\hline $\begin{array}{l}\text { C. Pulling the opponent and turn him to the } \\
\text { left side and escape from Kesa Gatame } \\
\text { skill. }\end{array}$ & 4.39 & 12.24 & 7.78 & 4.39 & $* 8.71$ & 77.23 \\
\hline $\begin{array}{l}\text { D. Pulling the opponent and turn him to the } \\
\text { left side and Oseekamy by Kesa Gatame } \\
\text { skill. }\end{array}$ & 4.14 & 4.20 & 7.53 & 4.70 & $* 10.25$ & 81.89 \\
\hline $\begin{array}{l}\text { E. Pushing the opponent upwards and } \\
\text { moving in a circle to the right side and } \\
\text { escape from Kami Shiho Gatame skill. }\end{array}$ & 4.64 & 8.01 & 8.14 & 4.05 & $* 10.56$ & 75.38 \\
\hline $\begin{array}{l}\text { F. Pushing the opponent upwards and } \\
\text { moving in a circle to the right side and } \\
\text { OseeKomy by Kami Shiho Gatame skill. }\end{array}$ & 4.78 & 4.47 & 8 & 3.55 & $* 12.17$ & 67.16 \\
\hline $\begin{array}{l}\text { G. Pushing the opponent upwards and } \\
\text { moving in a circle to the left side and } \\
\text { escape from Kami Shiho Gatame skill. }\end{array}$ & 5.96 & 10.85 & 8.35 & 3.05 & $* 5.71$ & 40.11 \\
\hline $\begin{array}{l}\text { H. Pushing the opponent upwards and } \\
\text { moving in a circle to the left side and } \\
\text { OseeKomy by Kami Shiho Gatame skill. }\end{array}$ & 4.35 & 4.97 & 7.67 & 4.22 & $* 10.75$ & 76.22 \\
\hline $\begin{array}{l}\text { I. Pushing the opponent's head with the } \\
\text { arm and moving the leg around his neck } \\
\text { to the right side and escape from Yoko } \\
\text { Shiho Gatame skill. }\end{array}$ & 4.64 & 8.01 & 8.39 & 3.43 & $* 10.24$ & 08.67 \\
\hline $\begin{array}{l}\text { J. Pushing the opponent's head with the } \\
\text { arm and moving the leg around his neck } \\
\text { to the right side and OseeKomy by Yoko } \\
\text { Shiho Gatame skill. }\end{array}$ & 4.78 & 4.47 & 8.60 & 3.43 & $* 12.21$ & 79.85 \\
\hline $\begin{array}{l}\text { K. Pushing the opponent's head with the } \\
\text { arm and moving the leg around his neck } \\
\text { to the left side and escape from Yoko } \\
\text { Shiho Gatame skill. }\end{array}$ & 4.57 & 9.66 & 8.07 & 3.25 & $* 8.61$ & 76.56 \\
\hline $\begin{array}{l}\text { L. Pushing the opponent's head with the } \\
\text { arm and moving the leg around his neck } \\
\text { to the left side and OseeKomy by Yoko } \\
\text { Shiho Gatame skill. }\end{array}$ & 5.60 & 6.32 & 8.17 & 4.44 & $* 8.28$ & 45.85 \\
\hline
\end{tabular}

Table 4 indicated that there are statistically post tests and there is a progress ratio in all the significant differences between the pre and the variables of the skill tests of the experimental 
group in favor of the post test. The researcher attributes the progress of the skill tests studied to the proposed training program because it contains a various groups of motor skills and different methods of training, and this gives the beginners the chance to choose the best skills that suit the situations they are in. This also increases the beginners' ability to cheat and change the plans in different directions to achieve a powerful speedy performance and coordination and to resist the opponent's attack plans. The proposed training program led also to improve the beginners' ability to choose the best way to perform a skill of Katame.Waza using Oseekomy.Waza skills in order to control the opponent and to overcome their fear of turning their body from the vertical position, the best position, to the horizontal position.

The researcher attributes these differences in the skill performance level to containing the program various exercises by using tools (constructive mode - climbing ropes) that are based on performing jumps, rotations and other exercises. This leads to strengthen the leg and back muscles, to keep the abilities of the beginners' bodies to perform the skill in the different directions and to perform the defence and the counter-attack skills rapidly.
The performance level is the result of the player training state in the skill, plan, physical and psychological aspects. Besides, it works on managing the mutual effects of the internal and external powers, which affect the beginner, aiming at making use of them to achieve the best results. ( Abd Elraouf , 2006) .

Training programs are the comprehensive development of the various skills and the aspects mentioned. The ability to change the body direction or a part of it and merge the motor skills together help the body to take the right position that suits the skill performance.Besides, developing the basic motor capabilities (flexibility, endurance, speed) helps the muscular groups to be coordinated. (Gaber , 2001).

All results are agreed with (Mohamed, 2007) and (Saad, 1999)'s indications that the training program help in improving the motor capabilities, accordingly, developing the skill performance. All this proved the second hypothesis that there are statistically significant differences between the pre and post tests of the experimental group in the performance level of some defence and counter-attack skills of Oseekomy.Waza for both sides of the body in Katame.Waza skills studied in favor of the post test, and there is a progress ratio. 
Table 5: Significant differences and progress ratio between the two pre tests of the control group and the experimental group in the physical and skill tests

$(n 1=n 2=56)$

\begin{tabular}{|c|c|c|c|c|c|c|}
\hline \multirow{2}{*}{ Physical tests } & \multicolumn{2}{|c|}{ Control group } & \multicolumn{2}{|c|}{ Experimental group } & \multirow{2}{*}{$\begin{array}{c}\text { T. } \\
\text { Test }\end{array}$} & \multirow{2}{*}{$\begin{array}{l}\text { Progress } \\
\%\end{array}$} \\
\hline & Mean & $\begin{array}{r}\text { Standard } \\
\text { deviation }\end{array}$ & Mean & $\begin{array}{r}\text { Standard } \\
\text { deviation }\end{array}$ & & \\
\hline $\begin{array}{l}\text { A. Uchi Komi with moving backwards to measure } \\
\text { (response speed) from the right side. }\end{array}$ & 0.797 & V.r.r & Y.TVA & $.7 V$. & $* 0.70$ & 114.74 \\
\hline $\begin{array}{l}\text { B. Uchi Komi with moving backwards to measure } \\
\text { (response speed) from the left side. }\end{array}$ & $\leqslant . \leqslant 7 \leqslant$ & .991 & r.AOV & $.0 V_{1}$ & $*\rceil . \vee \wedge$ & $07 . T_{0}$ \\
\hline $\begin{array}{l}\text { C. Circular throwing, by the different skills, test to } \\
\text { measure (muscular endurance) from the right } \\
\text { side. }\end{array}$ & 9.0 & $1.77 \mathrm{~V}$ & $1 \leq .4$ & 1.479 & $* I r . V V$ & $\varepsilon \vee . V \varepsilon$ \\
\hline $\begin{array}{l}\text { D. Circular throwing, by the different skills, test to } \\
\text { measure (muscular endurance) from the left side } \\
\text {. }\end{array}$ & $V . Y I \leq$ & $1 . r 09$ & ס & $\cdot .7 \cdot \Lambda \varepsilon$ & $* 11.10$ & $\varepsilon r .07$ \\
\hline $\begin{array}{l}\text { E. Uchi Mata semi-circular test to measure (agility) } \\
\text { from the right side. }\end{array}$ & rד.rq & r.rk & YI.1 & $1.7 \lambda r$ & $* 1 r . \leq 7$ & $r \varepsilon . \wedge r$ \\
\hline $\begin{array}{l}\text { F. Uchi Mata semi-circular test to measure (agility) } \\
\text { from the left side. }\end{array}$ & YV.Aq & $\leqslant .0 \leqslant$ & TY.TV & 1.11 & $* 11.09$ & rY. .99 \\
\hline $\begin{array}{l}\text { G. Side- throwing, by the different skills, test to } \\
\text { measure (speedy power) from the right side. }\end{array}$ & 0.0 & r.or & $9 . \leqslant r$ & . & *Ir.ir & $V_{T}$ \\
\hline $\begin{array}{l}\text { H. Side- throwing, by the different skills, test to } \\
\text { measure (speedy power) from the left side. }\end{array}$ & $\leq . \wedge T)$ & r.^q & $V . r$ & .719 & $* 1$. $\vee 0$ & ะ9.7 \\
\hline $\begin{array}{l}\text { I. Pulling the opponent and turn him to the right } \\
\text { side and escape from Kesa Gatame skill. }\end{array}$ & $\varepsilon .94$ & 0.99 & $\Lambda . r$ & r.vr & $* 0.0 \mathrm{~V}$ & 82.538 \\
\hline $\begin{array}{l}\text { J. Pulling the opponent and turn him to the right } \\
\text { side and Oseekamy by Kesa Gatame skill. }\end{array}$ & 0.11 & 0.7 & $\vee . \wedge 9$ & $\leqslant .0 \leqslant$ & $* \varepsilon . \vee_{0}$ & $0 \leqslant 0 \leqslant$ \\
\hline $\begin{array}{l}\text { K. Pulling the opponent and turn him to the left } \\
\text { side and escape from Kesa Gatame skill. }\end{array}$ & $\leq V \backslash \leq$ & r.r & $\vee . \vee \wedge$ & $\varepsilon .49$ & $* \varepsilon .9$ & 70.10 \\
\hline $\begin{array}{l}\text { L. Pulling the opponent and turn him to the left } \\
\text { side and Oseekamy by Kesa Gatame skill. }\end{array}$ & $\varepsilon . V Y$ & $0.1 \mathrm{~V}$ & V.or & $\varepsilon . \gamma \cdot$ & $* \varepsilon . \vee_{0}$ & $09 . \wedge \varepsilon$ \\
\hline $\begin{array}{l}\text { M. Pushing the opponent upwards and moving in a } \\
\text { circle to the right side and escape from Kami } \\
\text { Shiho Gatame skill. }\end{array}$ & $\varepsilon .97$ & 7. V. & $\wedge .1 \leq$ & $\varepsilon .0$ & $* 0.1 \mathrm{r}$ & $T \varepsilon . \cdot T$ \\
\hline $\begin{array}{l}\text { N. Pushing the opponent upwards and moving in a } \\
\text { circle to the right side and OseeKomy by Kami } \\
\text { Shiho Gatame skill. }\end{array}$ & 0 & $\varepsilon . r \varepsilon$ & $\wedge$ & $r .00$ & שוד. & 7. \\
\hline $\begin{array}{l}\text { O. Pushing the opponent upwards and moving in a } \\
\text { circle to the left side and escape from Kami } \\
\text { Shiho Gatame skill. }\end{array}$ & $7.1 \mathrm{~V}$ & 11.11 & N.ro & $r .0$ & *ץ. & ro.ru \\
\hline
\end{tabular}




\begin{tabular}{|c|c|c|c|c|c|c|}
\hline \multirow{2}{*}{ Physical tests } & \multicolumn{2}{|c|}{ Control group } & \multicolumn{2}{|c|}{ Experimental group } & \multirow{2}{*}{$\begin{array}{l}\text { T. } \\
\text { Test }\end{array}$} & \multirow{2}{*}{$\begin{array}{l}\text { Progress } \\
\%\end{array}$} \\
\hline & Mean & $\begin{array}{l}\text { Standard } \\
\text { deviation }\end{array}$ & Mean & $\begin{array}{l}\text { Standard } \\
\text { deviation }\end{array}$ & & \\
\hline $\begin{array}{l}\text { P. Pushing the opponent upwards and moving in a } \\
\text { circle to the left side and OseeKomy by Kami } \\
\text { Shiho Gatame skill. }\end{array}$ & \&.Or & $\varepsilon .7 r$ & $V .7 V$ & $\varepsilon . r$ & $* 0.01$ & 79.49 \\
\hline $\begin{array}{l}\text { Q. Pushing the opponent's head with the arm and } \\
\text { moving the leg around his neck to the right side } \\
\text { and escape from Yoko Shiho Gatame skill. }\end{array}$ & $\varepsilon \vee \wedge$ & $\Lambda . r \leq$ & 1.rq & $r . \leqslant r$ & $* 0.7$ & vo.rv \\
\hline $\begin{array}{l}\text { R. Pushing the opponent's head with the arm and } \\
\text { moving the leg around his neck to the right side } \\
\text { and OseeKomy by Yoko Shiho Gatame skill. }\end{array}$ & $\varepsilon .9 T$ & $\varepsilon .01$ & ^. 7 . & $r . \varepsilon r$ & $* 7.91$ & $V \varepsilon .7 T$ \\
\hline $\begin{array}{l}\text { S. Pushing the opponent's head with the arm and } \\
\text { moving the leg around his neck to the left side } \\
\text { and escape from Yoko Shiho Gatame skill. }\end{array}$ & 0 & 9.00 & A. $\cdot V$ & r.to & $* \leqslant .0 \leqslant$ & $7 . \leqslant r$ \\
\hline $\begin{array}{l}\text { T. Pushing the opponent's head with the arm and } \\
\text { moving the leg around his neck to the left side } \\
\text { and OseeKomy by Yoko Shiho Gatame skill. }\end{array}$ & 0.71 & 7.9 & ^. IV & $\varepsilon . \varepsilon \varepsilon$ & $* \varepsilon .11$ & $\leqslant 0 . \wedge 0$ \\
\hline
\end{tabular}

Table 5 shows the differences between the control group and the experimental group in the post skill and physical tests in favor of the experimental, and that is because of the positive effect of the physical program that leads to improve the motor capabilities of the experimental group. This has a positive effect on the skills progress. The program includes various skill exercises that increase the required effect of the training and raise the beginners' performance level. 
Table $^{\top}:$ Matrix of the correlation coefficient between the motor capabilities and the skill tests of the experimental group

\begin{tabular}{|c|c|c|c|c|c|c|c|c|}
\hline $\begin{array}{l}\text { Motor capabilties } \\
\text { Skill tests }\end{array}$ & $\begin{array}{l}\text { Resp. } \\
\text { speed } \\
\text { (right }\end{array}$ & $\begin{array}{l}\text { Resp. } \\
\text { speed } \\
\text { (left) }\end{array}$ & $\begin{array}{l}\text { Muscul } \\
\text { ar } \\
\text { endura } \\
\text { nce } \\
\text { (right) }\end{array}$ & $\begin{array}{l}\text { Musc. } \\
\text { Endur- } \\
\text { ance } \\
\text { (left) }\end{array}$ & $\begin{array}{l}\text { Agility } \\
\text { (right) }\end{array}$ & $\begin{array}{l}\text { Agility } \\
\text { (left) }\end{array}$ & $\begin{array}{l}\text { Speedy } \\
\text { power } \\
\text { (right) }\end{array}$ & $\begin{array}{l}\text { Speedy } \\
\text { power } \\
\text { (left) }\end{array}$ \\
\hline $\begin{array}{l}\text { A. Escaping to the right side } \\
\text { from Kesa Gatame skill. }\end{array}$ & 0.162 & $* 0.895$ & $* 0.860$ & -0.292 & *-0.929 & $*_{-} 0.790$ & $*_{-} 0.790$ & $* 0.783$ \\
\hline $\begin{array}{l}\text { B. OseeKomy.Waza from } \\
\text { the right side by Kesa } \\
\text { Gatame skill. }\end{array}$ & 0.107 & $* 0.942$ & $* 0.842$ & -0.312 & $*_{-0.919}$ & $*_{-} 0.845$ & $*_{-0.845}$ & $* 0.818$ \\
\hline $\begin{array}{l}\text { C. Escaping to the left side } \\
\text { from Kesa Gatame skill. }\end{array}$ & 0.023 & $* 0.972$ & $* 0.818$ & -0.333 & $*_{-} 0.887$ & $*_{-0.767}$ & $*_{-} 0.903$ & $* 0.751$ \\
\hline $\begin{array}{l}\text { D. OseeKomy.Waza from } \\
\text { the left side by Kesa } \\
\text { Gatame skill. }\end{array}$ & -0.087 & $* 0.907$ & $* 0.791$ & -0.407 & $*_{-} 0.858$ & $*_{-} 0.708$ & $*_{-} 0.884$ & $* 0.726$ \\
\hline $\begin{array}{l}\text { E. Escaping to the right side } \\
\text { from Kami Shiho } \\
\text { Gatame skill. }\end{array}$ & 0.186 & $* 0.915$ & $* 0.891$ & -0.291 & $*_{-} 0.944$ & $*_{-0.788}$ & $*_{-0.788}$ & $* 0.793$ \\
\hline $\begin{array}{l}\text { F. OseeKomy.Waza from } \\
\text { the right side by Kami } \\
\text { Shiho Gatame skill. }\end{array}$ & -0.024 & $* 0.949$ & $* 0.795$ & -0.335 & $*_{-} 0.848$ & $*_{-} 0.755$ & $*_{-0.906}$ & $* 0.702$ \\
\hline $\begin{array}{l}\text { G. Escaping to the left side } \\
\text { from Kami Shiho } \\
\text { Gatame skill. }\end{array}$ & 0.109 & $* 0.858$ & $* 0.797$ & -0.297 & *-0.906 & $*_{-} 0.804$ & $*_{-0.804}$ & $* 0.769$ \\
\hline $\begin{array}{l}\text { H. OseeKomy.Waza from } \\
\text { the left side by Kami } \\
\text { Shiho Gatame skill. }\end{array}$ & -0.064 & $* 0.937$ & $* 0.795$ & -0.408 & $*_{-0.857}$ & $*_{-0.688}$ & $*_{-} 0.873$ & $* 0.684$ \\
\hline $\begin{array}{l}\text { I. Escaping to the right side } \\
\text { from Yoko Shiho } \\
\text { Gatame skill. }\end{array}$ & 0.233 & $* 0.855$ & $* 0.867$ & -0.274 & $*_{-0.964}$ & $*_{-} 0.741$ & $*_{-} 0.741$ & $* 0.782$ \\
\hline $\begin{array}{l}\text { J. OseeKomy.Waza from } \\
\text { the right side by Yoko } \\
\text { Shiho Gatame skill. } \\
\end{array}$ & 0.280 & $* 0.822$ & $* 0.954$ & -0.273 & $*_{-} 0.885$ & $*_{-} 0.643$ & $*_{-} 0.643$ & $* 0.805$ \\
\hline $\begin{array}{l}\text { K. Escaping to the left side } \\
\text { from Yoko Shiho } \\
\text { Gatame skill. } \\
\end{array}$ & -0.059 & *0.928 & $* 0.757$ & -0.337 & $*_{-} 0.828$ & $*_{-} 0.756$ & $*_{-} 0.914$ & $* 0.687$ \\
\hline $\begin{array}{l}\text { L. OseeKomy.Waza from } \\
\text { the left side by Yoko } \\
\text { Shiho Gatame skill. }\end{array}$ & 0.292 & $* 0.913$ & $* 0.908$ & -0.273 & $*_{-0.998}$ & $*_{-0.738}$ & $*_{-} 0.738$ & $* 0.806$ \\
\hline
\end{tabular}

Table 6 indicated that there is a correlation between the motor capabilities tests and the skill tests except (Uchi Komi test with moving backwards to measure the response speed of the right side and Uchi Mata test, semi-circular, to measure the speed of reaction and agility). The researcher argues that this is because of the effect of the training program. Also, these tests measure the speed of reaction and agility. Besides, these skills are performed by the attacker, so he/she does not need to such performances. Judo is a kind of sport that requires a great deal of various defence and attack movements and physical abilities because it is characterized by unrepeated movements. Therefore, it requires special skills because it is based on speed, agility and endurance. The muscles on the upper part of the body should be strength to do the movements of seizing, pulling and throwing, and the lower part muscles are important for crawling, pushing and holding. Since judo skills are performed according to the sudden change of the game situations, it needs regard for the motor capabilities. 
Developing the skill and physical state of the player is important to improve his/her physical fitness entirely because the player cannot develop his/her skill performance level if the physical capabilities level is not sufficient. Therefore, we should care about training process components which aim at developing and improving the physical capabilities associated with the skill performance of the methods that form the defence and attack skills. (M. Ahmed, 2005)

The aim of designing training programs is to develop all the aspects (plan, skill, physical, psychological) as well as developing the different skills and the basic motor capabilities (flexibility, endurance, speed). The aim also is to find coordination between the muscular groups of the body. (A. Khayria, 2001). All this proved the third hypothesis that there is a correlation between the motor capabilities studied and the performance level of some defence and counter-attack skills.

\section{Conclusion}

1- Training programs have a positive effect on improving the beginners' motor capabilities.

2- Training programs have a positive effect on improving the beginners' motor capabilities and the performance level of the defence and counter-attack skills.

3- Increasing the progress rate of the skill and motor capabilities of the beginners' gives them self-confidence and speed in performing escape and counter-attack skills.

\section{Recommendations}

1- It is necessary to use training programs for developing motor capabilities because they have an effect on developing the judo skills and Katame.Waza skills specifically.

2- It is necessary to care about training the judo beginners the Katame.Waza skills because they have an obvious effect on the games results.
3- It is necessary to make a connection between the defence skills and the counterattack skills during training as they have a great effect on the games results of the judo player.

4- It is important to give the trainers courses to learn how to design training programs for developing motor capabilities.

\section{References}

Abd Elkhalik, E. (2005). Sports Training Theories and Applications, $9^{\text {th }}$ edition, Dar AlMaaref, Alex.pp: 25.

Aba Elmoneim, H. (2004). The effect of using sports shows on the emotional aspect of the primary stage at the east Tanta educational region, M.A., Faculty of Physical Education for Boys, Alex.

Abd Elraouf, Y.(2005). Judo and the $21^{\text {st }}$ Century, $1^{\text {st }}$ edition, Dar el-Esraa, Cairo. pp: 135

Abd Elraouf, Y. Uosaf, A. (2006). Judo for Children and Beginners, $1^{\text {st }}$ edition, Cairo. pp: 52.

Ahmed, A. (2008). Sports Training Psychology of the Beginners, $1^{\text {st }}$ edition, Dar Al-Fekr AlAraby, Cairo. pp: 88.

Angus,R. (2005). Competitive Judo Includes Developing the Technical Skills. pp: 35.

Fathy,A. (2004). Designing a multi-purposes training tool and its effect on the motor capabilities of some skills in gymnasium, M.A., Faculty of Physical Education for Boys, Alex. University. pp: 12

Gaber, M. (2001). Series of the Integrated Training for Champion Making 6-18 years old, Part 2, Monshaat Al-Maaref, Alex. pp: 88

Hamdy, A. (2009). Sports Training, Dar AlManhal, Zagazig · pp:151-152. 
Hamed, M. (2008). The Bases of JudoTraining, Dar Matbaat el-Amal, Cairo. pp:10.

Hamed, M. (2010). Modern Training Methods in Judo, $2^{\text {nd }}$ edition, Dar Assalam, Cairo. pp:133.

Hikoichi,H. (2000). Kodokan Judo, Translated by Horrson, Great Britain. pp: :26.

Husein, N. ( 2010). Judo Arts, 2nd edition, Dar Al-Manhal, Zagazig,

Ibrahim,K.,Gaber,M., (2001). Series of the Integrated Training for Champion Making 6-18 years old, Part 2, Monshaat Al-Maaref, Alex. pp: 88.

Mahmoud,A., Mohamed, A.(2005). Training Programs of the Kata Motor Skills in Karate, Monshaat Al-Maaref, Alex. pp: 68.

Mohamed, M. (2007). The effect of Training Program to Improve Certain Motor Capabilities of Feet Movements of Tennis Beginners, M.A., Faculty of Physical Education, Tanta University.

Mohamed,O. (1990).The effect of proposed training program on developing the motor sensory perception and some cognitive and emotional processes of the primary stage students, PhD., Faculty of Physical Education for Girls, Alex. University.

Moto,Y.(2004).The researcher of Training and Counters the Centre of Culture, Japanese. pp: 34.

Ohien,N.(2006). Judo Unleashed Includes Theory, Principles and Techniques, Also available in a UK . pp: 33.

Pedro, J. (2009). Judo Techniques and Tactics, Copyright, USA. pp: 38

Saad, S., (1999), The effect of Certain Motor Capabilities on the Effectiveness of Skill Performance to Kicks of Karate Players, beginners of 12-13 years old, M.A. (unpublished), Faculty of Physical Education for Boys, Alex. University.

Sobhy,M.(2000).Measurement and Evaluation in Sports and Physical Education, part2, 2nd edition, Dar Al-Fekr Al-Araby, Cairo. pp: 34.

Takahashashi, M. (2005). Mastering Judo Including Standing Combinations and Counters Physical Preparation, Published in May. pp: 32. 
